\title{
PRODUKSI DAN KARAKTERISTIK GELATIN HALAL BERBAHAN DASAR USUS AYAM
}

\section{PRODUCTION AND CHARACTERIZATION OF HALAL GELATINE MADE FROM CHICKEN INTESTINE}

\author{
Jajang Gumilar* dan Andri Pratama \\ Fakultas Peternakan, Universitas Padjajaran \\ J1. Bandung-Sumedang, KM 21, Jatinangor, Bandung, Jawa Barat \\ Email: j.gumilar@unpad.ac.id \\ Makalah: Diterima 21 Januari 2018; Diperbaiki 18 April 2018; Disetujui 25April 2018
}

\begin{abstract}
Gelatine is one of the most indispensable products in the food industry, pharmaceutical industry, photography industry, and other industries. Currently, the demand for gelatine in Indonesia is almost $100 \%$ fulfilled by gelatine imports from various countries. Imported gelatineare obtained from the hydrolysis of collagen from pigs and cattle body parts, which causes the anxiety of the Indonesian because the majority of Indonesian are moslems. Moslems forbid all types of food products derived from pigs and livestock that are not slaughtered using Islamic ways. Therefore, it is necessary to find out various raw materials alternatives to get halal gelatine. Gelatine can be made from various body tissues of livestock such as chicken intestines. The main ingredients of the intestine are proteins including collagen. Gelatine is obtained from collagen hydrolysis. Optimization of the acid concentration and soaking time at the demineralization stage influence to gelatine quality. This experiment was conducted experimentally, the design used was a complete randomized design with factorial pattern, the treatments were hydrochloric acid concentration (3, 5, and 7\%) and soaking time (24, 48, and 72 hours), each treatment was repeated four times. Variant analysis was used to determine the treatment difference, followed by Duncan's Multiple Range Test (DMRT) to test the differences between treatments. The results showed that there was an interaction between the use of hydrochloric acid concentration with the length of soaking time on the quality of chicken intestine gelatine. The use of 3\% hydrochloric acid with 24 hours soaking time resulted the best quality of chicken intestine gelatin, and had gelatine characteristic ie yield of $4.33 \%$; water content of $5.49 \%$; ash content $3.80 \%$; $\mathrm{pH} \mathrm{5.5;} \mathrm{and} \mathrm{gel} \mathrm{strength} \mathrm{of} 157.48 \mathrm{~g}$ bloom.
\end{abstract}

Keywords: gelatin, characterization, production, chicken intestine

\section{ABSTRAK}

Gelatin merupakan salah satu produk yang sangat dibutuhkan dalam industri pangan, industri farmasi, industri fotografi dan industri lainnya.Saat ini kebutuhan gelatin di Indonesia hampir 100\% dipenuhi oleh gelatin yang berasal dari impor berbagai Negara. Di luar negeri gelatin diperoleh dari hasil hidrolisis kolagen dari bagian tubuh ternak babi dan sapi, hal ini menyebabkan timbulnya kecemasan dari masyarakat Indonesia karena penduduk Indonesia mayoritas beragama Islam mengharamkan segala jenis produk bahan makanan yang berasal dari ternak babi dan ternak-ternak yang tidak disembelih menggunakan syariat Islam. Oleh karena itu perlu dicarikan berbagai alternatif bahan untuk mendapatkan gelatin halal. Gelatin dapat dibuat dari berbagai jaringan tubuh ternak seperti usus ayam. Kandungan utama dari usus adalah protein, diantaranya adalah kolagen. Gelatin diperoleh dari hasil hidrolisis kolagen. Optimasi penggunaan konsentrasi asam dan waktu perendaman pada tahap demineralisasi mempengaruhi kualitas gelatin. Penelitian ini dilakukan secara eksperimen, menggunakan rancangan acak lengkap pola faktorial penggunaan konsentrasi asam klorida (3, 5, dan 7\%) serta waktu perendaman $(24,48$, dan 72 jam), masing-masing perlakuan diulang empat kali. Analisis varian digunakan untuk mengetahui perbedaan perlakuan, dilanjutkan dengan Duncans Multiple Range Test (DMRT) untuk menguji perbedaan diantara perlakuan. Hasil penelitian menunjukkan bahwa terdapat interaksi antara penggunaan tingkat konsentrasi asam klorida dengan lama waktu perendaman terhadap kualitas gelatin usus ayam. Penggunaan asam klorida konsentrasi 3\% dengan lama perendaman 24 jam menghasilkan gelatin usus ayam dengan kualitas terbaik, rendemen sebanyak 4,33\%; kadar air 5,49\%; kadar abu 3,80\%; pH 5,5; dan kekuatan gel 157,48 g bloom

Kata kunci:, gelatin, karakteristik, produksi, usus ayam

\section{PENDAHULUAN}

Gelatin dihasilkan dari denaturasi kolagen triple helix pada larutan dengan suhu diatas $40^{\circ} \mathrm{C}$. Gelatin memiliki sifat fleksibel, berupa serabut yang tidak beraturan sebagai akibat dari pemecahan bentuk kolagen triple helix, sedangkan pada suhu dibawah $30^{\circ} \mathrm{C}$ kekuatan gelnya meningkat (Sarbon et al., 2015). Gelatin memiliki kemampuan membentuk gel, daya buih, dan emulsifikasi sehingga dapat digunakan pada berbagai industri seperti industri pangan, farmasi, fotografi, dan kosmetik. 
Kemampuan unik yang dimiliki gelatin adalah dapat membentuk gelyang revelsible pada panasyang hampir sama dengan suhu tubuh manusia serta larut di dalam air.

Saat ini kebutuhan gelatin di Indonesia hampir $100 \%$ dipenuhi oleh gelatin impor dari berbagai negara, seperti Cina, Australia, dan beberapa negara Eropa. Di luar negeri gelatin diperoleh dari hasil hidrolisis kolagen pada kulit, tulang, dan jaringan penghubung dari ternak babi dan ternak sapi. Lebih dari $90 \%$ penduduk Indonesia adalah pemeluk agama Islam yang tidak dapat mengkonsumsi pangan yang berasal dari ternak babi dan ternak lain yang disembelih tanpa mengikuti tatacara agama Islam. Oleh karena itu perlu dikembangkan pembuatan gelatin dari sumber bahan baku yang halal. Diantara sumber bahan baku gelatin yang belum banyak dikembangkan adalah hasil ikutan ternak unggas. Beberapa peneliti telah melakukan penelitian pembuatan gelatin dari hasil ikutan ternak unggas, seperti pembuatan gelatin dari kulit ayam (Sarbon et al., 2015; Nazmi et al., 2017) dan tulang ayam (Yasinet al., 2017). Selain kulit dan tulang, hasil ikutan ternak ayam lainnya adalah usus ayam.Usus ayam saat ini belum banyak digunakan, hanya dipakai sebagai pakan ikan lele atau produk pangan yang kurang digemari seperti sate usus dan kerupuk usus, padahal usus merupakan salah satu produk ikutan ternak yang memiliki kandungan protein tinggi.Hasil pengujian terhadap usus ayam ras di Laboratorium Nutrisi Makanan Ternak dan Kimia Makanan Ternak Universitas Padjadajaran tahun 2017 memiliki kandungan protein yang tinggi yaitu $32,66 \%$,sehingga memungkinkan untuk dibuat gelatin. Penelitian pembuatan gelatin dari usus belum banyak yang melaporkan.

Kualitas gelatin dipengaruhi oleh jenis spesies, jaringan, dan metode pengolahan (Sarbon et al., 2013). Metode pengolahan menjadi titik yang krusial dalam pembuatan gelatin. Berdasarkan metode pengolahannya, gelatin dibagi menjadi dua tipe yaitu tipe A dan tipe B. Tipe A dibuat dalam kondisi asam, sedangkan tipe B dibuat dalam kondisi basa. Asam mampu mengubah serat kolagen triple helix menjadi rantai tunggal, sedangkan larutan perendam basa hanya mampu menghasilkan rantai ganda. Hal ini menyebabkan pada waktu yang sama jumlah kolagen yang dapat dihidrolisis oleh larutan asam lebih banyak daripada larutan basa, olehkarena itu perendaman dalam larutan basa membutuhkan waktu yang lebih lama dalam menghidrolisis kolagen (Schrieber dan Gareis, 2007). Tahapan hidrolisis kolagen harus dilakukan dengan tepat (waktu dan konsentrasinya) jika tidak tepat kolagen akan larut secara sempurna di dalam pelarut sehingga menyebabkan penurunan rendemen gelatin yang dihasilkan.

Gelatin yang baik memiliki mutu sesuai dengan standar. Sifat fisik secara umum dan kadar unsur-unsur mineral tertentu menentukan nilai mutu gelatin. Sifat fisik yang paling utama pada mutu gelatin adalah nilai kekuatan gel yaitu kemampuan gelatin untuk berubah dari fase gel menjadi sol atau sebaliknya. Nilai kekuatan gel berdasarkan standar Lapi Gelatin adalah 80 - 300g Bloom. Standar mutu gelatin menurut Standar Nasional Indonesia (SNI06-3735-1995) yaitu: tidak berwarna, terkadang kekuningan; bau,rasa normal/dapat diterima konsumen; kadar air maksimum 16\%; kadar abu maksimum 3,25\%; logam berat maksimum 50 $\mathrm{mg} / \mathrm{kg}$; arsen maksimum $2 \mathrm{mg} / \mathrm{kg}$; tembaga maksimum $30 \mathrm{mg} / \mathrm{kg}$; seng maksimum $100 \mathrm{mg} / \mathrm{kg}$; sulfit maksimum $1000 \mathrm{mg} / \mathrm{kg}$.

Tujuan penelitian ini adalah untuk mengetahui proses produksi terbaik dan karakteristik gelatin berbahan dasar usus ayam.

\section{BAHAN DAN METODE}

\section{Bahan}

Usus yang digunakan adalah usus ayamras pedaging strain Cobsegar didapat dari pasar tradisional di Pasar Pangandaran Kabupaten Pangandaran, usus tersebut merupakan usus halal yang tidak mengandung unsur haram karena diproses, disimpan, diangkut, dan disajikan sesuai dengan syariat Islam (Estuti et al., 2005). Selama perjalanan menggunakan es sebagai pendingin sampai dengan tiba di laboratorium Teknologi Pengolahan Produk Peternakan, Fakultas Peternakan, Universitas Padjadjaran. Lemak yang dapat dilihat dibersihkan terlebih dahulu, kemudian dicuci dan ditimbang. $\mathrm{HCl}$ dan zat kimia lainnya menggunakan grade pa. produksi Merck. Alat yang digunakan pada penelitian ini adalah timbangan analitik (merek Sartorius, TE 214S), drying oven (Lab Companion), watter bath (Julabo, TW 20), pH meter (Hanna Instruments, HI 2211), Llyod Instrumnet Testing Machine (LRX 5K).

\section{Metode}

Metode penelitian yang digunakan adalah metode ekperimental dengan rancangan acak lengkap pola faktorial 2 X 3 . Faktor pertama adalah penggunaan konsentrasi asam klorida $(3,5$, dan $7 \%$ ) serta faktor kedua adalah waktu perendaman (24, 48, dan 72 jam). Masing-masing perlakuan diulang empat kali. Perbedaan perlakuan diuji menggunakan analisis varian, dan untuk menguji perbedaan diantara perlakuan dilanjutkan dengan uji Duncans Multiple Range Test (DMRT) (Gaspersz, 2002).

Pembuatan gelatin mengacu pada metode yang dikembangkan oleh Ockerman dan Hansen, (2000) dengan sedikit modifikasi, dimulai dari tahap degreasing dengan cara usus ayam direbus pada air mendidih selama 30 menit; kemudian dipotongpotong sepanjang $3 \mathrm{~cm}$; tahap demineralisasi dilakukan dengan cara usus direndam dalam larutan

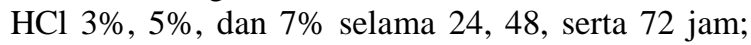
tahap netralisasi dilakukan dengan cara usus dicuci 
menggunakan air mengalir sampai dengan $\mathrm{pH}$ netral; tahap ekstraksi dilakukan menggunakan waterbath dengan suhu $80^{\circ} \mathrm{C}$ selama 7 jam; tahap penyaringan dilakukan menggunakan kertas saring Whatman no 42; pengeringan menggunakan drying oven pada suhu $50^{\circ} \mathrm{C}$ selama 24 jam; gelatin ditepungkan menggunakan blender kemudian dianalisa lebih lanjut untuk mengetahui kualitas gelatin yang dihasilkan.

\section{Rendemen (AOAC, 1995)}

Rendemen gelatin diperoleh dari perbandingan berat tepung gelatin kering yang dihasilkan dengan berat mentah bahan segar. Besar rendemen dapat ditentukan dengan menggunakan rumus sebagai berikut:

$$
\text { Rendemen }=\frac{\text { Berat tepung gelatin kering }}{\text { Berat potongan usus ayam }} \times 100 \%
$$

\section{Kadar Air (AOAC, 1995)}

Cawan porselen dikeringkan pada suhu $105^{\circ} \mathrm{C}$ selama 1 jam. Kemudian didinginkan dan ditimbang. Sampel yang akan ditentukan kadar airnya ditimbang sebanyak 5g. Cawan yang telah berisi sampel dimasukkan ke dalam oven bersuhu $105^{\circ} \mathrm{C}$ sampai beratnya konstan. Kadar air dihitung berdasarkan rumus sebagai berikut:

$$
\text { Kadar Air }(\%)=\frac{\text { B }- \text { C }}{\text { B }- \text { A }} \times 100 \%
$$

Keterangan :

$\mathrm{A}=$ berat cawan kosong

$\mathrm{B}=$ berat cawan + sampel awal $(\mathrm{g})$

$\mathrm{C}=$ berat cawan + sampel setelah dioven $(\mathrm{g})$

\section{Kadar Abu (AOAC, 1995)}

Sampel yang diuapkan airnya dimasukkan ke dalam tanur bersuhu $600^{\circ} \mathrm{C}$, sebelumnya berat cawan kering dan berat contoh telah diketahui. Proses penguapan dilakukan sampai semua bahan berubah warna menjadi abu-abu, kemudian sample ditimbang. Kadar abu dihitung dengan rumus sebagai berikut:

$$
\text { Kadar Abu }(\%)=\frac{\text { Berat abu }}{\text { Berat sampel }} \times 100 \%
$$

\section{pH (AOAC, 1995)}

Sampel sebanyak 0,2 gditimbang dan dilarutkan ke dalam $20 \mathrm{ml}$ air pada suhu $25^{\circ} \mathrm{C}$. Sampel dihomogenkan dengan magnetic stirrer, kemudian diukur derajat keasamannya pada suhu kamar dengan $\mathrm{pH}$ meter.

\section{Kekuatan Gel (British Standard 757, 1975)} Larutan gelatin dengan konsentrasi $6,67 \%(\mathrm{~b} / \mathrm{v})$ disiapkan dengan aquades ( $7 \mathrm{~g}$ gelatin ditambah aquadest $105 \mathrm{ml})$. Larutan diaduk menggunakan magnetic stirrer sampai homogen kemudia dipanaskan sampai suhu $60^{\circ} \mathrm{C}$ selama 15 menit. Tuang larutan dalam Standard Bloom Jars (botol dengan diameter $58-60 \mathrm{~mm}$, tinggi 85 $\mathrm{mm}$ ), tutup dan diamkan selama 2 menit. Inkubasi pada suhu $10^{\circ} \mathrm{C}$ selama $16-18$ jam. Selanjutnya diukur menggunakan alat TA-XT plus texture analyzer pada kecepatan probe $0,5 \mathrm{~mm} /$ detik dengan kedalam $4 \mathrm{~mm}$. Kekuatan gel dinyatakan dalam satuan g bloom.

\section{HASIL DAN PEMBAHASAN}

\section{Rendemen Gelatin Usus Ayam}

Rendemen gelatin merupakan hasil gelatin kering yang dapat diekstraksi dari usus ayam sebagai bahan baku yang digunakan. Berdasarkan hasil penelitian dihasilkan rendemen gelatin dari usus ayam sebagaimana tertera pada Tabel 1 .

Tabel 1. Pengaruh konsentrasi dan lama perendaman dalam HClterhadap rendemen gelatin dari usus ayam

\begin{tabular}{cccc}
\hline $\begin{array}{c}\text { Konsentr } \\
\text { asi }\end{array}$ & \multicolumn{3}{c}{ Lama perendaman (jam) } \\
\hline HCl & $\mathbf{2 4}$ & $\mathbf{4 8}$ & $\mathbf{7 2}$ \\
\hline & $\ldots \ldots \ldots \ldots \ldots \ldots \ldots \ldots \ldots \ldots \ldots \ldots \ldots \ldots \ldots \ldots \ldots \ldots \ldots \ldots \ldots \ldots \ldots \ldots$ \\
$3 \%$ & ${ }_{\mathrm{B}} 4,33^{\mathrm{c}}$ & ${ }_{\mathrm{A}} 1,69^{\mathrm{b}}$ & ${ }_{\mathrm{A}} 0,44^{\mathrm{a}}$ \\
$5 \%$ & ${ }_{\mathrm{A}} 1,40^{\mathrm{b}}$ & ${ }_{\mathrm{A}} 0,95^{\mathrm{a}}$ & ${ }_{\mathrm{A}} 0,65^{\mathrm{a}}$ \\
$7 \%$ & ${ }_{\mathrm{A}} 1,12^{\mathrm{a}}$ & ${ }_{\mathrm{A}} 1,09^{\mathrm{a}}$ & ${ }_{\mathrm{A}} 0,58^{\mathrm{a}}$ \\
\hline
\end{tabular}

Keterangan: huruf kecil yang berbeda kearah baris dan hurup besar kearah kolom menunjukkan berbeda nyata $(\mathrm{p}<0,05)$.

Data pada Tabel 1 menunjukkan bahwa rendemen gelatin yang dihasilkan dari usus ayam berkisar antara $0,44 \%$ sampai dengan $4,33 \%$, masing-masing dihasilkan dari proses demineralisasi menggunakan $\mathrm{HCl}$ sebanyak 3\% direndam selama 72 jam serta demineralisasi menggunakan $\mathrm{HCl} 3 \%$ direndam selama 24 jam. Hasil tersebut juga memberikan gambaran bahwa semakin lama waktu perendaman dengan $\mathrm{HCl}$ menghasilkan rendemen yang lebih sedikit.

Hasil analisis ragam menunjukkan bahwa terdapat interaksi antara konsentrasi asam klorida yang digunakan dan waktu perendaman terhadap rendemen gelatin yang dihasilkan. Uji lanjut menggunakan DMRT menunjukkan bahwa penggunaan $\mathrm{HCl}$ sebanyak 3\% yang direndam selama 24 jam menghasilkan gelatin berbeda nyata $(\mathrm{p}<0,05)$ lebih banyak dibandingkan dengan perendaman 48 dan 72 jam, serta perendaman 48 memberikan rendemen yang berbeda nyata $(p<0,05)$ lebih banyak dibandingkan dengan perendaman selama 72 jam. Penggunaan $\mathrm{HCl} 5 \%$ juga memberikan hasil rendemen yang berbeda terhadap waktu perendaman, perendaman selama 24 jam menghasilkan rendemen berbeda nyata $(p<0,05)$ lebih banyak dibandingkan dengan rendemen hasil 
perendaman selama 48 dan 72 jam, sedangkan perendaman selama 48 dan 72 jam masing-masing tidak berbeda nyata $(\mathrm{p}>0,05)$. Penggunaan $\mathrm{HCl} 7 \%$ tidak menunjukkan perbedaan besaran rendemen secara nyata $(p>0,05)$. Perendaman selama 24 jam menunjukkan hasil rendemen yang berbeda nyata $(\mathrm{p}<0,05)$ lebih besar pada penggunaan $\mathrm{HCl}$ sebanyak $3 \%$ dibandingkan dengan penggunaan $\mathrm{HCl}$ sebanyak $5 \%$ dan $7 \%$, sedangkan perendaman selama 24 jam ini tidak menunjukkan hasil yang berbeda nyata dengan menggunakan $\mathrm{HCl}$ sebanyak 5 dan $7 \%$. Perendaman selama 48 jam tidak menghasilkan rendemen yang berbeda nyata $(\mathrm{p}>0,05)$ pada penggunaan $\mathrm{HCl} 5$ dan $7 \%$.

Hasil penelitian menunjukkan bahwa produksi gelatin dari usus ayam paling baik $(4,33 \%)$ menggunakan $\mathrm{HCl}$ sebanyak $3 \%$ yang direndam selama 24 jam. Rendemen ini lebih besar dari hasil penelitian produksi gelatin sisik ikan sebesar 1,08 $3,45 \%$ (Le et al., 2015), dan hampir sama dengan produksi gelatin dari kulit ikan sebanyak $4-16 \%$ (Binsi et al., 2009), tetapi lebih rendah dibandingkan dengan gelatin yang diproduksi dari kulit ayam sebesar 6,67\% (Sarbon et al., 2013). Peningkatan penggunaan $\mathrm{HCl}$ dan peningkatan waktu perendaman menyebabkan semakin kecil rendemen gelatin yang dihasilkan karena asam klorida termasuk dalam asam kuat, semakin tinggi penggunaan asam klorida maka kadar asam pada larutan semakin tinggi sehingga tidak hanya menghidrolisis struktur triple helix kolagen menjadi struktur yang tidak beraturan tetapi dapat menghidrolisis peptida sampai dengan rantai asam aminonya, sehingga hasil ekstraksi gelatin menjadi lebih sedikit. Perendaman yang terlalu lama dan terlalu kuat konsentrasi zat perendamnya dapat menyebabkan kolagen terdegradasi dan hancur sempurna sehingga gelatin tidak dapat dihasilkan (Ockerman dan Hansen, 2000) .

\section{Kadar Air Gelatin Usus Ayam}

Kadar air yang terkandung dari gelatin yang diproduksi dari usus ayam dapat dilihat pada Tabel 2. Kadar air gelatin hasil penelitian berkisar antara 3,79 sampai dengan 5,50\%. Semakin tinggi kandungan asam klorida pada larutan, semakin rendah kadar air gelatin yang dihasilkan, begitu juga semakin lama perendaman dilakukan pada usus maka kadar air gelatin yang dihasilkan pun semakin kecil. Peningkatan konsentrasi asam menyebabkan semakin banyak ion $\mathrm{H}^{+}$pada larutan perendam. Hal ini menyebabkan kolagen yang terhidrolisis semakin banyak, jumlah grup hydrophobic meningkat pada permukaan molekul protein dan terjadi penurunan ukuran molekulnya sehingga menurunkan kapasitas penyimpanan air (Yasin et al., 2017).

Hasil uji statistika menunjukkan bahwa penggunaan asam klorida sebanyak $3 \%$ menghasilkan gelatin dengan kadar air yang tidak berbeda pada perendaman 24 dan 48 jam, tetapi berbeda nyata $(p<0,05)$ lebih tinggi dari lama perendaman selama 72 jam, begitu juga perendaman selama 48 jam berbeda nyata $(\mathrm{p}<0,05)$ lebih besar dibandingkan dengan perendaman selama 72 jam.

Tabel 2. Pengaruh konsentrasi dan lama perendaman dalam $\mathrm{HCl}$ terhadap kadar air gelatin dari usus ayam

\begin{tabular}{cccc}
\hline Konsentrasi & \multicolumn{3}{c}{ Lama perendaman (jam) } \\
\hline HCl & $\mathbf{2 4}$ & $\mathbf{4 8}$ & $\mathbf{7 2}$ \\
\hline & $\ldots \ldots \ldots \ldots \ldots \ldots \ldots \ldots \ldots \ldots \ldots \ldots \ldots \ldots \ldots \ldots \ldots \ldots \ldots$ \\
$3 \%$ & ${ }_{\mathrm{A}} 5,49^{\mathrm{b}}$ & ${ }_{\mathrm{B}} 5,50^{\mathrm{b}}$ & ${ }_{\mathrm{B}} 4,59^{\mathrm{a}}$ \\
$5 \%$ & ${ }_{\mathrm{A}} 5,45^{\mathrm{b}}$ & ${ }_{\mathrm{AB}} 4,91^{\mathrm{b}}$ & ${ }_{\mathrm{A}} 3,79^{\mathrm{a}}$ \\
$7 \%$ & ${ }_{\mathrm{A}} 5,06^{\mathrm{a}}$ & ${ }_{\mathrm{A}} 4,37^{\mathrm{a}}$ & ${ }_{\mathrm{AB}} 4,50^{\mathrm{a}}$ \\
\hline
\end{tabular}

Keterangan: huruf kecil yang berbeda kearah baris dan hurup besar kearah kolom menunjukkan berbeda nyata $(\mathrm{p}<0,05)$.

Penggunaan asam klorida sebanyak 5\% menunjukkan pola yang sama dengan penggunaan $3 \%$. Penggunaan asam klorida sebanyak $7 \%$ yang digunakan sebagai perendam usus ayam menghasilkan gelatin dengan kandungan air yang tidak berbeda nyata pada berbagai lama waktu perendaman. Waktu perendaman selama 24 jam dan konsentrasi asam klorida tidak memberikan pengaruh nyata $(\mathrm{p}>0,05)$ pada kadar air yang dihasilkan oleh gelatin tersebut. Waktu perendaman selama 48 jam dengan konsentrasi asam klorida 3 dan 5\% menghasilkan gelatin dengan kadar air yang berbeda nyata $(\mathrm{p}<0,05)$ lebih tinggi daripada menggunakan asam klorida 7\%, sedangkan perendaman selama 48 jam dengan asam klorida $3 \%$ dan $5 \%$ tidak menunjukkan perbedaan nyata $(\mathrm{p}>0,05)$. Perendaman usus ayam selama 72 jam dengan berbagai konsentrasi asam klorida tidak menghasilkan gelatin dengan kadar air berbeda nyata $(\mathrm{p}>0,05)$. Nilai kadar air gelatin yang dihasilkan pada penelitian ini sesuai dengan standar gelatin yaitu maksimum 16\% (SNI-06-3735-1995), dan hampir sama dengan kadar air gelatin dari kulit kambing berkisar 4,52-6,04 g/100g (Mad-Ali et al., 2016)

\section{Kadar Abu}

Kadar abu gelatin yang dihasilkan dari usus ayam memiliki kandungan yang berbeda-beda sebagaimana dapat dilihat pada Tabel 3. Kadar abu gelatin dari usus ayam berkisar antara $1,18 \%$ sampai $3,80 \%$. Kadar abu tertinggi dihasilkan dari gelatin hasil perlakuan perendaman menggunakan asam klorida konsentrasi 3\% dengan lama perendaman selama 24 jam, sedangkan akar abu terkecil dihasilkan dari demineralisasi menggunakan perendam asam klorida konsentrasi $7 \%$ selama 72 jam. Semakin lama waktu perendaman menghasilkan gelatin dengan kadar abu semakin rendah, dan semakin tinggi penggunaan asam klorida juga menghasilkan gelatin dengan kadar abu yang 
rendah pula. Semakin tinggi konsentrasi asam pada larutan perendam dan semakin lama waktu perendaman menyebabkan semakin banyak kalsium yang terlarut pada cairan perendam, sehingga kandungan kalsium pada usus ayam yang akan diekstraksisemakin berkurang. Hal ini menyebabkan kalsium yang ikut terekstrak bersama gelatin semakin menurun. Menurunnya kandungan kalsium pada gelatin menyebabkan penurunan kadar abu. Proses yang digunakan terutama proses hidrolisis kolagen dan jenis bahan baku dapat menyebabkan perbedaan komposisi kimia gelatin yang dihasilkan (Mad-Ali et al., 2016).

Tabel 3. Pengaruh konsentrasi dan lama perendaman dalam $\mathrm{HCl}$ terhadap kadar abu gelatin dari usus ayam

\begin{tabular}{|c|c|c|c|}
\hline Konsentrasi & \multicolumn{3}{|c|}{ Lama perendaman (jam) } \\
\hline $\mathrm{HCl}$ & 24 & 48 & 72 \\
\hline & \multicolumn{3}{|c|}{$\%$} \\
\hline $3 \%$ & ${ }_{B} 3,80^{b}$ & ${ }^{2} 2,42^{\mathrm{a}}$ & ${ }_{\mathrm{B}} 2,34^{\mathrm{a}}$ \\
\hline $5 \%$ & ${ }_{A}^{2} 2,68^{b}$ & $\mathrm{~A}^{2}, 20^{\mathrm{b}}$ & ${ }_{\mathrm{A}} 1,51^{\mathrm{a}}$ \\
\hline $7 \%$ & ${ }^{2} 2,33^{b}$ & ${ }^{2} 2,34^{b}$ & ${ }_{\mathrm{A}} 1,18^{\mathrm{a}}$ \\
\hline
\end{tabular}

Keterangan: huruf kecil yang berbeda kearah baris dan hurup besar kearah kolom menunjukkan berbeda nyata $(\mathrm{p}<0,05)$.

Hasil analisis statistika menunjukkan bahwa terdapat interaksi antara konsentrasi asam klorida dan waktu perendaman terhadap kadar abu gelatin yang dihasilkan. Penggunaan asam klorida 3\% selama 24 jam menghasilkan gelatin dengan kadar abu berbeda nyata $(p<0,05)$ lebih besar daripada perendaman selama 48 dan 72 jam, sedangkan perendaman usus ayam selama 48 dan 72 jam masing-masing tidak memberikan perbedaan nyata pada kadar abu gelatin yang dihasilkan $(\mathrm{p}>0,05)$. Penggunaan asam klorida dengan konsentrasi 5\% yang digunakan sebagai perendam usus ayam selama 24 dan 48 jam tidak memberikan perbedaan kadar abu, sedangkan perendaman selama 72 jam menghasilkan gelatin dengan kadar abu berbeda nyata $(\mathrm{p}<0,05)$ lebih kecil dari pada perendaman selama 24 dan 48 jam. Perendaman menggunakan asam klorida sebanyak $7 \%$ menghasilkan gelatin dengan pola yang sama dengan penggunaan asam klorida sebanyak 5\%. Hampir seluruh hasil penelitian ini menghasilkan kadar abu sesuai dengan standar gelatin di Indonesia yaitu maksimum 3,25\% (SNI-06-3735-1995). Hasil penelitian ini juga menghasilkan gelatin dengan kadar abu yang mirip dengan kadar abu gelatin ikan sebesar 2,92 g/100g (Rahman et al., 2009).

\section{Kadar pH}

Kadar $\mathrm{pH}$ menunjukkan tingkat keasaman gelatin hasil penelitian. Tingkat keasaman gelatin hasil penelitian dapat dilihat pada Tabel 4.
Tabel 4. Pengaruh konsentrasi dan lama perendaman dalam $\mathrm{HCl}$ terhadap kadar $\mathrm{pH}$ gelatin dari usus ayam

\begin{tabular}{cccc}
\hline \multirow{2}{*}{$\begin{array}{c}\text { Konsentrasi } \\
\text { HCl }\end{array}$} & \multicolumn{3}{c}{ Lama perendaman (jam) } \\
\cline { 2 - 4 } & $\mathbf{2 4}$ & $\mathbf{4 8}$ & $\mathbf{7 2}$ \\
\hline & $\ldots \ldots \ldots \ldots \ldots \ldots \ldots \ldots \ldots \ldots \ldots \ldots \ldots \ldots \ldots \ldots \ldots \ldots \ldots \ldots \ldots \ldots \ldots \ldots \ldots \ldots$ & $\% \ldots \ldots \ldots$ \\
$3 \%$ & ${ }_{\mathrm{B}} 5,55^{\mathrm{a}}$ & $\mathrm{C} 5,65^{\mathrm{a}}$ & $\mathrm{B} 5,35^{\mathrm{a}}$ \\
$5 \%$ & $\mathrm{~A} 4,50^{\mathrm{a}}$ & $\mathrm{B} 4,60^{\mathrm{a}}$ & $\mathrm{B} 5,70^{\mathrm{b}}$ \\
$7 \%$ & $\mathrm{~A} 4,45^{\mathrm{b}}$ & $\mathrm{A} 3,05^{\mathrm{a}}$ & $\mathrm{A} 4,50^{\mathrm{b}}$ \\
\hline
\end{tabular}

Keterangan: huruf kecil yang berbeda kearah baris dan hurup besar kearah kolom menunjukkan berbeda nyata $(\mathrm{p}<0,05)$.

Kandungan $\mathrm{pH}$ gelatin dari usus ayam berkisar antara 3,05 sampai dengan 5,70\%, masingmasing dihasilkan dari perendaman menggunakan asam klorida $7 \%$ dengan lama perendaman 48 jam dan perendaman menggunakan asam klorida 5\% dan lama perendaman 72 jam. Gelatin yang dihasilkan dari penelitian ini memiliki kandungan pH yang semakin kecil seiring dengan peningkatan konsentrasi asam klorida yang digunakan, sedangkan lama perendaman tidak memberikan kecenderungan yang serupa. Semakin meningkat konsentrasi asam klorida pada larutan menyebabkan jumlah ion $\mathrm{H}^{+}$ meningkat, hal tersebut menyebabkan ion $\mathrm{H}^{+}$yang terpenetrasi ke dalam gelatin semakin banyak sehingga kadar $\mathrm{pH}$ semakin menurun.

Hasil uji sidik ragam menunjukkan bahwa terdapat perbedaan nyata diantara konsentrasi asam klorida dan waktu perendaman, juga terdapat interaksi diantara kedua faktor tersebut. Uji lanjut menggunakan Duncan Multiple Range Test menunjukkan bahwa penggunaan asam klorida 3\% dengan lama perendaman 24, 48, dan 72 jam tidak menghasilkan perbedaan nyata pada kandungan $\mathrm{pH}$ gelatin. Penggunaan asam klorida 5\% dengan lama perendaman 24 dan 48 jam menghasilkan gelatin dengan kandungan $\mathrm{pH}$ tidak berbeda nyata $(\mathrm{p}>0,05)$, tetapi perendaman selama 72 jam menghasilkan $\mathrm{pH}$ berbeda nyata $(p>0,05)$ lebih tinggi dari pada perendaman selama 24 dan 48 jam. Penggunaan asam klorida $7 \%$ sebagai perendam usus ayam selama 24 jam menghasilkan gelatin dengan kandungan $\mathrm{pH}$ tidak berbeda nyata $(\mathrm{p}>0,05)$ dengan perendaman selama 72 jam, tetapi berbeda nyata $(\mathrm{p}<0,05)$ lebih tinggi dibandingkan dengan perendaman selama 48 jam, dan perendaman selama 72 jam juga menghasilkan gelatin dengan $\mathrm{pH}$ berbeda nyata $(\mathrm{P}<0,05)$ dibandingkan dengan perendaman selama 48 jam. Perendaman selama 24 jam menggunakan asam klorida 3\% menghasilkan gelatin dengan kandungan $\mathrm{pH}$ berbeda nyata $(\mathrm{p}<0,05)$ lebih tinggi dibandingkan dengan menggunakan asam klorida 5\% dan 7\%. Perendaman selama 48 jam menghasilkan gelatin dengan kandungan $\mathrm{pH}$ tidak berbeda nyata $(\mathrm{p}>0,05)$. Perendaman usus ayam selam 72 jam menggunakan asam klorida 3 dan 5\% menghasilkan gelatin dengan nilai tidak berbeda nyata $(p>0,05)$, sedangkan 
menggunakan asam klorida 7\% menghasilkan gelatin dengan kandungan $\mathrm{pH}$ berbeda nyata $(\mathrm{p}<0,05)$ lebih kecil dibandingkan dengan menggunakan asam klorida 3 dan $5 \%$. pH terbaik pada peneltian ini adalah 5,7 dan sebagian besar kandungan $\mathrm{pH}$ pada penelitian ini masih sesuai dengan standar yang ditetapkan oleh GME yaitu antara 3,8 sampai 7,6. Kandungan $\mathrm{pH}$ gelatin sangat dipengaruhi oleh proses netralisasi, sisa asam yang terdapat pada usus ayam akan mempengaruhi kandungan $\mathrm{pH}$ gelatin yang dihasilkan. Proses asam akan menghasilkan gelatin dengan kandungan $\mathrm{pH}$ yang lebih asam dibandingkan dengan proses basa (Schrieber dan Gareis, 2007).

\section{Kekuatan Gel}

Kekuatan gel pada gelatin hasil penelitian dapat dilihat pada Tabel 5. Kekuatan gel gelatin yang dihasilkan dari penelitian ini berkisar antara 92,21 sampai $157,48 \mathrm{~g}$ bloom. Semakin lama perendaman menghasilkan gelatin dengan kekuatan gel semakin menurun, sedangkan peningkatan konsentrasi asam klorida tidak memberikan pola yang seragam. Hasil analisa sidik ragam menunjukkan bahwa terdapat perbedaan nyata diantara faktor konsentrasi asam klorida dan waktu perendaman, serta terdapat interaksi diantara kedua faktor tersebut. Hasil uji lanjut menggunakan uji Duncan menunjukkan bahwa konsentrasi asam klorida 3\% pada perendaman 24 jam menghasilkan gelatin dengan nilai kekuatan gel berbeda nyata $(\mathrm{p}<0,05)$ lebih tinggi dari perendaman selama 48 dan 72 jam, sedangkan lama perendaman 48 dan 72 jam menghasilkan gelatin dengan nilai kekuatan gel tidak berbeda nyata $(\mathrm{p}>0,05)$. Penggunaan asam klorida $5 \%$ dengan lama perendaman 24 jam menghasil gelatin dengan kekuatan gel berbeda nyata $(\mathrm{p}<0,05)$ lebih besar dibandingkan dengan perendaman selama 48 dan 72 jam, dan perendaman selama $48 \%$ menghasilkan gelatin yang meiliki keuatan gel berbeda nyata $(\mathrm{p}<0,05)$ lebih tinggi dibandingkan dengan perendaman selam 72 jam. Penggunaan asam klorida 7\% menghasilkan gelatin dengan kekuatan gel tidak berbeda nyata ( $p>0,05)$. pada perendaman 24, 48, dan 72 jam. Waktu perendaman selam 24 jam menghasilkan gelatin dengan kekuatan gel tidak berbeda nyata $(p>0,05)$ pada penggunaan berbagai konsentrasi asam klorida. Perendaman selama 48 jam menggunakan asam klorida 3\% menghasilkan gelatin dengan kekuatan gel tidak berbeda nyata ( $>0,05)$ dibandingkan dengan menggunakan asam klorida $7 \%$ tetapi berbeda nyata $(\mathrm{p}<0,05)$ lebih besar dibandingkan dengan menggunakan asam klorida $5 \%$, dan penggunaan asam klorida 5\% menghasilkan gelatin dengan nilai kekuatan gel berbeda nyata ( $>0$,05) paling kecil. Perendaman selama 72 jam menghasilkan gelatin dengan kekuatan gel dengan pola yang sama dengan perendaman selama 48 jam.
Tabel 5. Pengaruh konsentrasi dan lama perendaman dalam $\mathrm{HCl}$ terhadap kekuatan gel gelatin dari usus ayam

\begin{tabular}{|c|c|c|c|}
\hline \multirow{2}{*}{$\begin{array}{c}\text { Konsentrasi } \\
\mathrm{HCl} \\
\end{array}$} & \multicolumn{3}{|c|}{ Lama perendaman (jam) } \\
\hline & 24 & 48 & 72 \\
\hline & & g Bloom... & $\ldots \ldots \ldots . . . . .$. \\
\hline $3 \%$ & ${ }_{A} 157,48^{b}$ & в $137,65^{\mathrm{a}}$ & в $128,27^{\mathrm{a}}$ \\
\hline $5 \%$ & ${ }_{\mathrm{A}} 144,70^{\mathrm{c}}$ & ${ }_{\mathrm{A}} 119,83^{\mathrm{b}}$ & ${ }_{\mathrm{A}} 92,21^{\mathrm{a}}$ \\
\hline $7 \%$ & ${ }_{\mathrm{A}} 144,95^{\mathrm{a}}$ & в $143,36^{\mathrm{a}}$ & B $132,42^{\mathrm{a}}$ \\
\hline
\end{tabular}

Keterangan: huruf kecil yang berbeda kearah baris dan hurup besar kearah kolom menunjukkan berbeda nyata $(\mathrm{p}<0,05)$.

Perendaman menggunakan asam klorida 3\% selama 24 jam menghasilkan kualitas gelatin yang paling baik sebesar 157,48 $\mathrm{g}$ bloom memenuhi standar GMIA 50 - $300 \mathrm{~g}$ bloom, dan termasuk gelatin yang memiliki kekuatan gel sedang antara 150 - 200 (Sarbon et al., 2013). Perbedaan kekuatan gel diantara perlakuan dapat disebabkan karena semakin lama perendaman menyebabkan degradasi protein semakin banyak sehingga rantai peptida menjadi lebih pendek yang memungkinkan dapat menurunkan kemampuan membentuk ikatan peptida satu dengan yang lainnya, ikatan peptida yang lebih panjang dapat membentuk agrerasi membentuk ikatan gel yang lebih efektif, hal ini menjadi indikasi terhadap peningkatan kekuatan gel (Kaewdang et al., 2015). Kekuatan gel juga dapat disebabkan oleh kandungan hidroksiprolinnya, semakin tinggi kandungan hidroksiprolin maka kekuatan gel akan meningkat. Hidroksiprolin menyebabkan ikatan hidrogen diantara molekul air dengan gugus hidroksil bebas pada gelatin menjadi lebih stabil, sehingga dapat meningkatkan kekuatan gel (Sompie et al., 2012). Penurunan kekuatan gel terjadi karena semakin lama waktu perendaman meningkatkan waktu kontak antara larutan asam dengan protein usus ayam sehingga semakin banyak protein terdegradasi, hal ini menyebabkan semakin banyak fragmen-fragmen protein dan menurunkan kemampuan gelatin berubah menjadi gel. Molekul gelatin dengan rantai pendek tidak dapat membentuk ikatan molekul yang kuat, terutama pada ikatan hidrogen atau ikatan lemah lainnya seperti interaksi hidropobik dan interaksi ionik (Kittiphattanabawon et al., 2016).

\section{KESIMPULAN DAN SARAN}

Terdapat interaksi antara penggunaan tingkat konsentrasi asam klorida dengan lama waktu perendaman terhadap kualitas gelatin dari usus ayam. Penggunaan asam klorida konsentrasi 3\% dengan lama perendaman 24 jam menghasilkan gelatin usus ayam yang memiliki kualitas terbaik dengan parameter rendemen sebanyak 4,33\%; kadar air 5,49\%; kadar abu 3,80\%; pH 5,5; dan kekuatan gel $157,48 \mathrm{~g}$ bloom. 


\section{UCAPAN TERIMA KASIH}

Penelitian ini dilaksanakan menggunakan program hibah internal Universitas Padjadjaran, Tahun anggaran 2017.

\section{DAFTAR PUSTAKA}

[AOAC] Association of Official Analytical and Chemists. 1995. Official Methods of Analysis the $16^{\text {th }}$ ed. Virginia: Inc. Arlington.

Badan Standardisasi Nasional. SNI-06-3735-1995 Mutu dan Cara Uji Gelatin. Departemen Perindustrian. Jakarta.

Binsi PK, Shamasundar BA, Dilep AO, Badli F. Howell NK. 2009. Rheological and funtional properties of gelatin from the skin of biegeye snapper (Priacanthus Hamrur) fish: influence of gelatin on the gel-forming abillity of fish mince. Food Hydrocolloids. 23: $132-245$.

British Standard 757. 1975. Sampling and testing of gelatin. Di dalam The Science and Technology of Gelatin. Ward AG dan Courts A, editors. New York: Academic Press.

Estuti W, Syarief R, dan Hermanianto J. 2005. Pengembangan konsep jaminan halal di rumah potong ayam (studi kasus pada industri daging ayam). Jurnal Teknologi. dan Industri Pangan. XVI (3): 239-246.

Gaspersz V. 2002. Teknik analisis dalam penelitian percobaan. Jilid 1. Bandung: Tarsito.

[GME] Gelatin Manufactures of Europe. 2017. Standardised methods for the testing of edible gelatine. Secretariat Gelatin Manufacturers of Europe. Brusel. 7.

[GMIA] Gelatin Manufacturers Institute of America. 2012. Gelatin handbook. North America. 12

Kaewdang O, Benjakul S, Prodpran T, Kaewmanee, T, Kishimura H. 2015. Characteristics of gelatin from swim bladder of yellowfin tuna (Thunnus albacores) as influenced by extracting temperatures. Italia Journal Food Science. 27: 366 - 374.

Kittiphanattanabawon P, Benjakul S, Sinthusamran, S, Kishimura H. 2016. Gelatin from clown featherback skin: Extraction Condition. Food Science Technology. 66: 186-192.
Le T, Maki H, Takahashi K Okazaki E, Osako K. 2015. Properties of gelatin film from horse mackerel (Trachurus japonicus) Scale. Journal Food Science. 80 (4): 34 - 41.

Mad-Ali S, Benjakul S, Prodpran T, Maqsood S. 2016. Interfacial properties of gelatin from goat skin as influenced by drying methods. Food Science Technology 73: 102 - 107.

Nazmi NN, Isa MIN, dan Sarbon NM. 2017. Preparation and characterization of chicken skin gelatin/ cmc composite film as compared to bovine gelatin film. Food Biosci. 19: 149 - 155.

Ockerman HW dan Hansen CL. 2000. Animal ByProduct Processing and Utilization. CRC Press. USA.

Rahman MS dan Al-Mahrouqi. 2009. Instrumental texture profile analysis of gelatin gel extracted from grouper skin and commercial (Bovine and Porcine) Gelatin Gels. International Journal Food Science Nut. 60 (S7): $229-242$.

Sarbon NM, Badii F, dan Howell NK. 2013. Preparation and characterization of chicken skin gelatin as an alternative to mammalia gelatin. Food Hydrocolloids.30: 143 - 151.

Sarbon NMF dan Badii Howel K. 2015. The effect of chicken skin gelatin and whey protein interaction on rheological and thermal properties. Food Hydrocolloids. 45: $83-$ 92.

Schrieber R dan Garies H. 2007. Gelatin Handbook: Theory and Industrial Practice. Wiley$\mathrm{VCH}$.

Sompie M, Triatmojo S, Pertiwiningrum A, Pranoto Y. 2012. The effects of animal age and acetic acid concentration on pig skin gelatin characteristics. Journal Indonesian Tropical Animal Agriculture. 37(3): 176 182.

Yasin H, Babji AS, dan Norrakiah AS. 2017. Modification of chicken feet gelatin with aqueous sweet basil and lemongrass extract. Food Science Technology. 77: 72 - 79. 